\title{
Spatial distributions and seasonal cycles of aerosol climate effects in India seen in a global climate-aerosol model
}

\author{
S. V. Henriksson ${ }^{1,2}$, J.-P. Pietikäinen ${ }^{1}$, A.-P. Hyvärinen ${ }^{1}$, P. Räisänen ${ }^{1}$, K. Kupiainen ${ }^{3,4}$, J. Tonttila ${ }^{1,2}$, R. Hooda ${ }^{1}$, \\ H. Lihavainen ${ }^{1}$, D. O'Donnell ${ }^{1}$, L. Backman ${ }^{1}$, Z. Klimont ${ }^{4}$, and A. Laaksonen ${ }^{1,5}$ \\ ${ }^{1}$ Finnish Meteorological Institute, Helsinki, Finland \\ ${ }^{2}$ Department of Physics, University of Helsinki, Finland \\ ${ }^{3}$ Finnish Environment Institute (SYKE), Helsinki, Finland \\ ${ }^{4}$ International Institute for Applied Systems Analysis (IIASA), Laxenburg, Austria \\ ${ }^{5}$ Department of Physics, University of Eastern Finland, Kuopio, Finland \\ Correspondence to: S. V. Henriksson (svante.henriksson@fmi.fi)
}

Received: 20 May 2013 - Published in Atmos. Chem. Phys. Discuss.: 5 July 2013

Revised: 15 July 2014 - Accepted: 23 July 2014 - Published: 24 September 2014

\begin{abstract}
Climate-aerosol interactions in India are studied by employing the global climate-aerosol model ECHAM5HAM and the GAINS inventory for anthropogenic aerosol emissions. Model validation is done for black carbon surface concentrations in Mukteshwar and for features of the monsoon circulation. Seasonal cycles and spatial distributions of radiative forcing and the temperature and rainfall responses are presented for different model setups. While total aerosol radiative forcing is strongest in the summer, anthropogenic forcing is considerably stronger in winter than in summer. Local seasonal temperature anomalies caused by aerosols are mostly negative with some exceptions, e.g., parts of northern India in March-May. Rainfall increases due to the elevated heat pump (EHP) mechanism and decreases due to solar dimming mechanisms (SDMs) and the relative strengths of these effects during different seasons and for different model setups are studied. Aerosol light absorption does increase rainfall in northern India, but effects due to solar dimming and circulation work to cancel the increase. The total aerosol effect on rainfall is negative for northern India in the months of June-August, but during March-May the effect is positive for most model setups. These differences between responses in different seasons might help converge the ongoing debate on the EHPs and SDMs. Due to the complexity of the problem and known or potential sources for error and bias, the results should be interpreted cautiously as they are completely dependent on how realistic the model is. Aerosol-
\end{abstract}

rainfall correlations and anticorrelations are shown not to be a reliable sole argument for deducing causality.

\section{Introduction}

Aerosols have a significant impact on human health, the environment and, through their effects on regional climate, on agriculture and other aspects of society. By scattering and absorbing radiation and modifying cloud properties, aerosols can affect heating at different height levels and the hydrological cycle. In India, with its agriculture depending on the monsoon rains to feed a large population, this has strong importance for human society.

Literature results from modeling and measurements consistently report a strong negative aerosol forcing at the surface and strong atmospheric heating in India (Ramanathan et al., 2001, 2007; Ramanathan and Feng, 2009; Chung and Ramanathan, 2006; Padma Kumari et al., 2007; Niranjan et al., 2007; Meehl et al., 2008; Ramanathan and Carmichael, 2008; Stier et al., 2007; Marcq et al., 2010; Pathak et al., 2010; Verma et al., 2011). Two main types of mechanisms by which aerosols influence monsoon rainfall have been proposed: firstly, solar dimming mechanisms (SDMs; Xu, 2001; Chung and Ramanathan, 2006; Ramanathan et al., 2005; Lau and Kim, 2010) indicating reduced rainfall due to a reduced north-south or land-ocean temperature gradient slowing down the monsoon circulation and reduced evaporation 
due to less absorbed sunlight at the surface; secondly, the elevated heat pump (EHP; Lau et al., 2006) hypothesis states that atmospheric heating at elevated levels due to light absorption by aerosols increases convection, cloud formation and rainfall. Despite having some observational support (Lau and Kim, 2006, 2010, 2011; Bollasina et al., 2008; de Laat et al., 2012), the EHP hypothesis has received also controversial responses (Kuhlmann and Quaas, 2010; Nigam and Bollasina, 2010, 2011), a large part, but not all, of them involving aerosol and rainfall properties during March-May, before the monsoon season. The sea surface temperature (SST) gradients take time to adjust to aerosol forcing; based on simulations coupling an atmospheric model to a slab ocean model, it has been suggested that the slow response through the ocean would be more important for precipitation (Ganguly et al., 2012a, b). Investigating the links from aerosol loading to effects on precipitation is a complex task due to a multitude of relevant, interplaying effects, many of which are non-local in space and time (Lau et al., 2008; Bollasina and Nigam, 2009; Levermann et al., 2009; Wang et al., 2009; Ganguly et al., 2012a, b; Lee et al., 2013).

While the state-of-the-art CMIP5 climate models generally project an increase in monsoon rainfall coupled with global warming (Menon et al., 2013), many models project reduced rainfall due to aerosol SDM effects (Ramanathan, 2005; Meehl et al., 2008), though this is debated as already mentioned. Therefore research facilitating this debate and understanding to converge is obviously needed.

In this article, we study aerosol-climate interactions with help of the global climate-aerosol model ECHAM5-HAM. Our goal is to provide a more detailed breakdown of the spatial distributions and seasonal cycles of the aerosol effects than before and an analysis of the underlying physics. We will separate direct and indirect effects, light absorbing from scattering, modification of cloud properties and the response of a mixed-layer ocean. We will investigate the SDM and EHP hypotheses and provide our input to the ongoing discussion, especially regarding the strength of different competing effects and their relative importance during different seasons.

The article is organized as follows: Sect. 2 describes the model, the emission inventory and the simulations done. Section 3 describes black carbon aerosol climatology in Mukteshwar and the comparison with measurements. Section 4 presents radiative forcing and temperature response in the simulations. Section 5 presents the monsoon climate simulated by the model and aerosol effects on rainfall, and Sect. 6 discusses making conclusions from correlations between aerosol optical depth (AOD) and rainfall, followed by conclusions in the last section.

\section{The model, the emission inventories and simulations}

The ECHAM5-HAM model (Stier et al., 2005; Roeckner et al., 2006b) is an atmospheric general circulation model (GCM) coupled with an aerosol model simulating five aerosol species in seven lognormal modes. The simulated species are sulfate (SU), black carbon (BC), organic carbon (OC), mineral dust (DU) and sea salt (SS). Aerosol transport, chemistry and removal are simulated. The aerosols affect the climate through their impact on shortwave radiation. Optionally, cloud activation by aerosols can be simulated. The model also includes an option of nudging. The model is described in more detail in Stier et al. (2005) and simulated large-scale aerosol distributions in India and China in Henriksson et al. (2011), where the model was evaluated against MODIS AOD seasonal cycles and spatial distributions and other measurements and shown to qualitatively reproduce large-scale aerosol properties in India and China. However, in two areas - the Ganges valley with large amounts of absorbing biomass aerosol and the Thar Desert with high dust load and high albedo - the correspondence was not that good. This does not necessarily mean that the model is wrong as MODIS has challenges over such areas (see Henriksson et al. ,2011, and references therein). For additional model evaluation in this article, we compare the modeled BC concentrations with those measured in Mukteshwar on the slopes of the Himalayas $\left(29^{\circ} 26^{\prime} \mathrm{N}, 79^{\circ} 37^{\prime} \mathrm{N}\right)$, an important area where biomass burning aerosols emitted in the Ganges valley are transported. The Mukteshwar measurement results have been analyzed earlier (Hyvärinen et al., 2009, 2011a, b; Komppula et al., 2009; Neitola et al., 2011) but have not been compared to climate model results before.

The model was run at horizontal resolution T42 (grid spacing of $2.8^{\circ}$ ) and 19 levels in the vertical in a hybrid sigma/pressure coordinate system, with the top level at $10 \mathrm{hPa}$. The coarse resolution brings limitations to resolve the multitude of small-scale convective and other processes over the complex terrain of the Himalayas (Medina et al., 2010). Abhik et al. (2013) also identified a potential bias related to moist physics and convection: northward propagation of convection anomalies is poorly simulated. Problems with modeling convection and parameterizing it realistically are also in general well-known limitations of GCMs (Miyamoto et al., 2013), but the main features of the monsoon are still simulated well, as discussed later in Sect. 5.

In most simulations, sea surface temperatures (SSTs) were prescribed using data from a simulation with the coupled model ECHAM5-MPIOM (Roeckner et al., 2003, 2006a; Marsland et al., 2003) assuming the IPCC A1B scenario for greenhouse gases (Nakicenovic et al., 2000). To account for effects of aerosol forcing on SSTs, two simulations were made by coupling the atmospheric model to a mixed-layer ocean model.

Cloud optical properties were computed based on their condensate amount and cloud droplet number concentration (CDNC), as described in Roeckner et al. (2003). In the runs with indirect effects included, the CDNC was prognosed by the aerosol scheme. In the runs without indirect effects, the CDNC was prescribed, varying from $50 \mathrm{~cm}^{-3}$ in the upper 
troposphere to $220(80) \mathrm{cm}^{-3}$ near the surface over land (over ocean). Lower and upper limits of 4 and $24 \mu \mathrm{m}$ were assumed for the effective radius of liquid cloud droplets. Scavenging was included following Stier et al. (2005).

The integrated assessment model GAINS (Greenhouse gas - Air pollution Interactions and Synergies; Amann et al., 2011; http://www.iiasa.ac.at/web/home/research/ researchPrograms/Program-Overview.en.html) has been used in policy and science discussions in Europe and Asia since a few decades (Tuinstra, 2007; Klimont et al., 2009). Here we use it to determine the anthropogenic emissions of $\mathrm{BC}, \mathrm{OC}$ and $\mathrm{SO}_{2}$ in 2005. The model includes all major economic sectors, information about existing environmental legislation and relies on peer-reviewed emission factors. While input data for India are typically available at the national level, GAINS offers finer spatial resolution. The development of the subnational level data relies on national statistics and has involved collaboration with TERI (The Energy Research Institute, India) (Purohit et al., 2010). The provincial-level emissions have been distributed into $0.5^{\circ} \times 0.5^{\circ}$ longitude-latitude using representative concentration pathways (RCP) consistent proxies as used and further developed within the Global Energy Assessment project (GEA, 2012).

The energy and domestic sector emissions are resolved on monthly scale. Monthly temporal patterns for the domestic heating and cooking were developed as well by combining the stove use assumptions presented by Streets et al. (2003) with the global gridded temperature fields from the CRU3.0 archive of monthly mean temperatures in 2005 (http://badc. nerc.ac.uk/data/cru/) (Brohan et al., 2006).

The international shipping emissions were developed using two data sources: (1) the global shipping from RCP (Eyring et al., 2010; Lamarque et al., 2010), and (2) a separate arctic area emissions database developed by Corbett et al. (2010). Some overlaps between the spatial grids were observed, and in those cases the Corbett et al. (2010) emission values were used.

The global and Indian emissions used as input for the climate modelings are presented in the Supplement.

The wildfire emissions are based on GFED 3 emission database (Giglio et al., 2010). To be consistent with the GAINS model emissions, we use the wildfire data for the year 2005. GFED 3 emissions include an agricultural wasteland burning sector, which is also present in the GAINS emissions. However, in this work, the GAINS agricultural waste burning emissions are used. Of natural emissions in the model, mineral dust, sea salt and ocean dimethyl sulfide (DMS) emissions are calculated online and others are prescribed. Natural emissions from wildfires were taken from the GFED3 inventory (van der Werf et al., 2010), Terrestrial biogenic DMS emissions in the model are prescribed according to Pham et al. (1995). $\mathrm{SO}_{2}$ emissions from volcanoes are based on Andres and Kasgnoc (1998) and Halmer et al. (2002), $\mathrm{SO}_{2}$ and biogenic particulate organic matter (POM) emissions on Guenther et al. (1995).

A total of 11 simulations were made in this study (Table 1). Nine simulations were made with fixed SSTs, two of which are treated as sensitivity calculations and two more simulations coupling the atmospheric model to a mixed-layer ocean model. Seven of the simulations (MAIN, ZERO, NOABS, SSTMODIF, NUDGE, MAIN_MLO and ZERO_MLO) were made without aerosol cloud activation. Thus, in these simulations the indirect effect of aerosols is not included, while the direct radiative effects and semidirect effect on cloudiness are considered. The MAIN simulation included anthropogenic emissions based on the GAINS inventory, while in the ZERO simulation, anthropogenic emissions were excluded. The NOABS and NUDGE simulations included anthropogenic emissions from the GAINS inventory but differed from the MAIN simulation as follows: in NOABS, aerosol single-scattering albedo was set to 1 , which eliminates aerosol absorption. As the aerosols are partly internally mixed (Stier et al., 2005), aerosol absorption was switched off for both black carbon and dust. The difference between the MAIN and NOABS simulations represents the impact of aerosol absorption compared to the same amount of scattering, thus also of a correspondingly stronger negative top of the atmosphere (TOA) forcing. Finally, in the NUDGE simulation, simulated vorticity, divergence, temperature, and surface pressure were nudged towards ERA-Interim reanalysis data (Dee et al., 2011).

As a sensitivity calculation, in SSTMODIF, SSTs were modified to study the effect of a potential aerosol-induced cooling of the northern Indian Ocean (NIO) compared to the equatorial Indian Ocean. Based on the observation that equatorial Indian Ocean has warmed, since the 1950s, by roughly $0.5 \mathrm{~K}$ more than the northern Indian Ocean (Ramanathan et al., 2005), a negative SST perturbation increasing linearly from $0 \mathrm{~K}$ at the Equator to $0.5 \mathrm{~K}$ at $20^{\circ} \mathrm{N}$ was added to the baseline SST field.

The difference between simulations with and without anthropogenic aerosols represents only a part of their full climate effect when using fixed SSTs. The difference between the mixed-layer ocean simulations MAIN_MLO and ZERO_MLO represents a more full physical response. However, SSTs in such models react only locally and possibly too strongly to radiative forcings (anonymous referee \#2, 2011; anonymous referee \#3, 2011). In ECHAM5-HAM coupled with a mixed layer model, unrealistically strong SST gradients have arisen in simulations with very strong aerosol forcing (A.I. Partanen, personal communication, 2013). Indeed, the mixed-layer ocean model became unstable when including aerosol cloud activation. A fully coupled model would in principle take the aerosol-climate effects into account best, but it was not computationally feasible to us and were such simulations to be made, further uncertainty would be created due to the added complexity. A further educated guess of the ocean response is accounted for in the SSTMODIF 
Table 1. The different simulations done, the anthropogenic emissions applied, aerosol light absorption (on/off), aerosol cloud activation (on/off) and SST field (standard: prescribed from coupled atmosphere-ocean model; see text).

\begin{tabular}{lllll}
\hline & Anthropogenic emissions & Absorption & Cloud activation & SST \\
\hline MAIN & GAINS & on & off & standard \\
ZERO & 0 & on & off & standard \\
NOABS & GAINS & off & off & standard \\
SSTMODIF (sensitivity calc.) & GAINS & on & off & $\Delta$ SST $=-0.5 \mathrm{~K}$ in NIO \\
NUDGE & GAINS & on & off & standard \\
MAIN_ACT & GAINS & on & on & standard \\
ZERO_ACT & 0 & on & on & standard \\
NOABS_ACT & GAINS & off & on & standard \\
SSTMODIF_ACT (sensitivity calc.) & GAINS & on & on & $\Delta$ SST $=-0.5 \mathrm{~K}$ in NIO \\
MAIN_MLO & GAINS & on & off & mixed-layer \\
ZERO_MLO & 0 & on & off & mixed-layer \\
\hline
\end{tabular}

experiment. The estimates obtained with the mixed-layer ocean take into account the largest number of components in the climate system of all the simulations.

The simulations MAIN_ACT, ZERO_ACT, NOABS_ACT and SSTMODIF_ACT included aerosol cloud activation according to Lin and Leaitch (1997). Otherwise, these simulations were similar to MAIN, ZERO, NOABS and SSTMODIF, respectively. Conducting these simulations both with and without aerosol activation is useful for assessing which aspects of the climate response are robust to changes in model formulation. Simulations were run for 8 years (2004-2011, but the years are not that important as emissions are at 2005 levels during all years) with the exception of the NUDGE and SSTMODIF simulations (6 years) and the mixed-layer ocean simulations, which were run for 50 years with only monthly mean values stored in the output. The first year of each simulation was discarded as a spin-up period when analyzing the results, and in the mixed-layer ocean simulations only the last 10 years were analyzed to allow the model to reach equilibrium.

\section{BC concentrations in Mukteshwar}

Emissions of carbonaceous aerosols are more uncertain than those of sulfate aerosols (Ohara et al., 2007; Klimont et al., 2009), and validating the concentrations is thus an essential part of evaluating how realistic the simulations are. Figure 1 shows a comparison of simulated daily surface BC concentrations at Mukteshwar (interpolated from grid points) with measurements. The simulation is NUDGE and the year is 2006. The time series follow each other quite well with a minimum in the winter, maxima in the spring and fall and a drop in the monsoon months, although the decrease starts later in the simulation. The precipitation field is not nudged, and the discrepancy is most likely due to significantly more wet removal in the real situation. Figure 2 shows multi-year monthly averages of the measured and modeled concentra- tions for the MAIN_ACT simulation including aerosol cloud activation. In this case, the drop in concentrations in the monsoon months of June and especially July and August is seen also in the simulation, though not as strongly as in the measurements. Modeled concentrations are larger in the winter months January and especially December, while spring and fall maxima are seen both in the simulation and in measurements. In general, $\mathrm{BC}$ and $\mathrm{OC}$ concentrations are smaller than in the previously published simulations using the REAS emission inventory (Henriksson et al., 2011) due to different emissions and a slightly different model version (we did not track down the detailed reasons behind the discrepancy, but a comparison between the AOD seasonal cycle in previously and presently presented simulations can be found in Supplement Fig. S1b).

\section{Radiative forcing and temperature response}

In this section, we present estimates for aerosol radiative forcing and the surface temperature response in the model. The seasonal cycle of radiative forcing in the simulations with GAINS emissions is shown in Fig. 3 for the top of the atmosphere (TOA) and for the surface in Fig. 4. The radiative forcing gives the instantaneous effect of aerosols on radiation; the effect including feedbacks will be discussed below. The anthropogenic forcing can be estimated as the difference between the radiative forcing in a simulation containing anthropogenic aerosols and that without them. The natural aerosols are causing total negative radiative forcing to be strongest in the summer, but anthropogenic forcing is much stronger in the winter than in the summer. In the summer months, the Indian average negative forcing is only a few tenths of watts per square meter. Figure 5 shows the spatial distribution of annual-mean anthropogenic forcing. The atmospheric forcing calculated as the difference between the TOA and surface forcings is shown in Supplement Fig. S3. The atmospheric forcing varies less during the year than the 


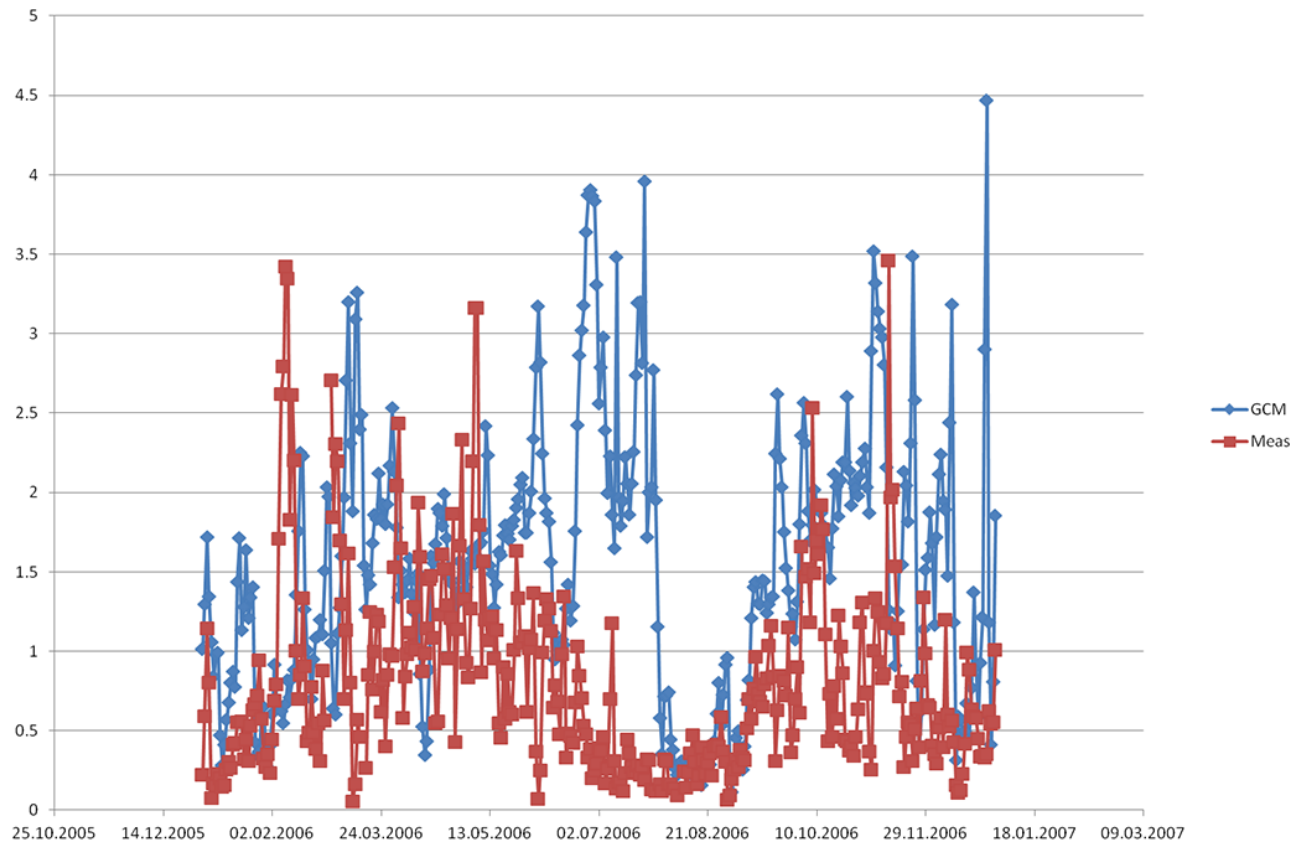

Figure 1. Surface BC concentration (in $\mu \mathrm{g} \mathrm{m}^{-3}$ ) in Mukteshwar measurements and in the grid point nearest to Mukteshwar in the NUDGE simulation, year 2006.

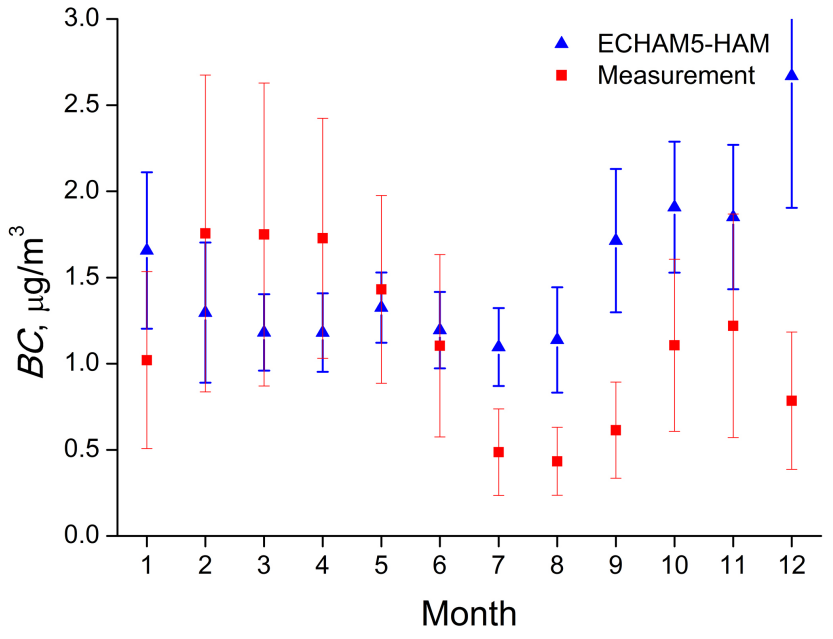

Figure 2. Surface BC concentration (in $\mu \mathrm{g} \mathrm{m}^{-3}$ ) in Mukteshwar measurements and in the MAIN_ACT simulation with GAINS emissions and aerosol cloud activation, 7-year monthly means with variability illustrated by standard deviation of daily values.

TOA and surface forcings and is on the order of $6 \mathrm{~W} \mathrm{~m}^{-2}$ when anthropogenic aerosols are included and on the order of $1 \mathrm{~W} \mathrm{~m}^{-2}$ without anthropogenic aerosols. Indeed, tropospheric temperature anomalies can be strongly positive, as discussed later and shown in Supplement Figs. S9 and S11.

Figure 6 shows the total radiation (shortwave plus longwave) anomalies. The anomalies include also the effect on cloud cover through semidirect and other feedbacks affecting

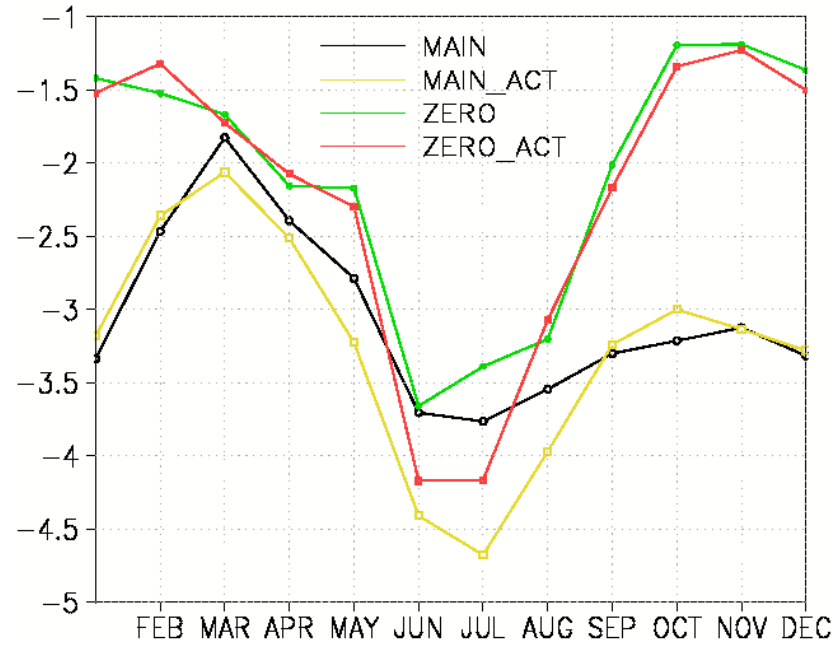

Figure 3. Seven-year monthly mean radiative forcing (in $\mathrm{W} \mathrm{m}^{-2}$ ) in the area $65-90^{\circ} \mathrm{E}, 5-35^{\circ} \mathrm{N}$ at the TOA in the MAIN and MAIN_ACT simulations with GAINS emissions without aerosol cloud activation (black) and with aerosol cloud activation (yellow) and in the ZERO the ZERO_ACT simulations without anthropogenic emissions without cloud activation (green) and with aerosol cloud activation (red)

the radiative balance (neglecting those adopting slowly, e.g., due to ocean thermal inertia). The surface anomalies are negative due to aerosols in all cases and so are the TOA anomalies in the simulation with aerosol cloud activation included, but in the simulation without aerosol-cloud activation, the 


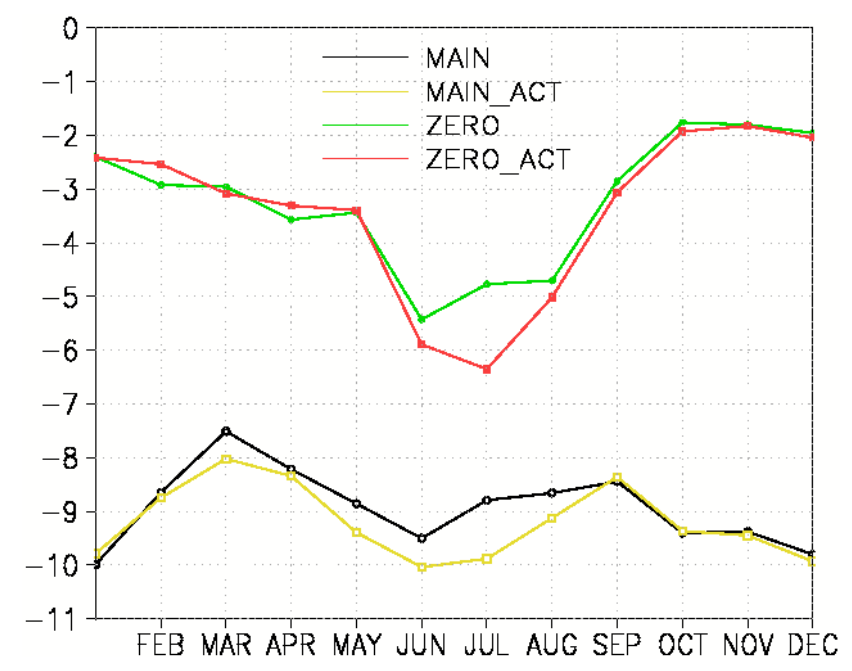

Figure 4. Seven-year monthly mean radiative forcing (in $\mathrm{W} \mathrm{m}^{-2}$ ) in the area $65-90^{\circ} \mathrm{E}, 5-35^{\circ} \mathrm{N}$ at the surface in the MAIN and MAIN_ACT simulations with GAINS emissions without aerosolcloud activation (black) and with aerosol-cloud activation (yellow) and in the ZERO and ZERO_ACT simulations without anthropogenic emissions without cloud activation (green) and with aerosol-cloud activation (red).

TOA radiation anomalies are positive in some months, especially May and June. This is shown in Supplement Fig. S4 to be for thw most part due to a longwave cloud feedback. The number of high clouds thus increases because of aerosols in the MAIN simulation so that the total TOA radiative flux anomaly becomes strongly positive in May and June. This is at least partly because of aerosol light absorption and increased upward vertical motion as will be seen later.

Figures 7 and 8 show anomalies of the $2 \mathrm{~m}$ air temperature in different seasons for the simulations with GAINS emissions both with and without aerosol-cloud activation, respectively, with the simulations with no anthropogenic emissions used as a reference. Figure 9 shows similar $2 \mathrm{~m}$ air temperature anomalies for the mixed-layer ocean model setup. Anomalies are similar with and without aerosol activation included and mostly negative, tending to be stronger with aerosol activation included and with the exception for northern India in March-May. A warming tropospheric temperature trend has been observed for these months in the western Himalayas (Prasad et al., 2009), which could partly be explained by aerosols according to our results (also see heightresolving plots in the next section) and has been argued by some authors to be consistent with the EHP hypothesis (Gautam et al., 2009; Lau and Kim, 2010). As will be seen in the next section, smaller climatological cloud cover in MarchMay in northern India might be related, as it allows the solar radiation to reach the absorbing aerosols in these months.

The mixed-layer ocean temperature anomalies look different than those for the atmospheric model. Northern India shows stronger negative anomalies, with the exception

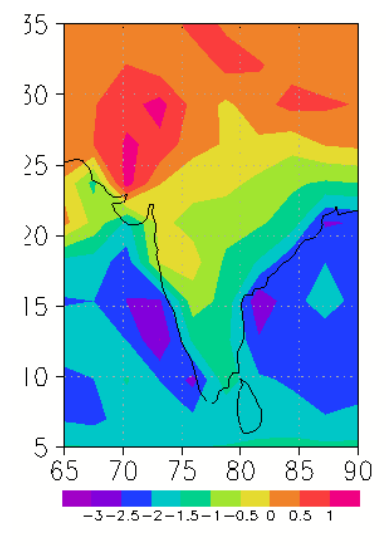

QxaS: COLA/6ES

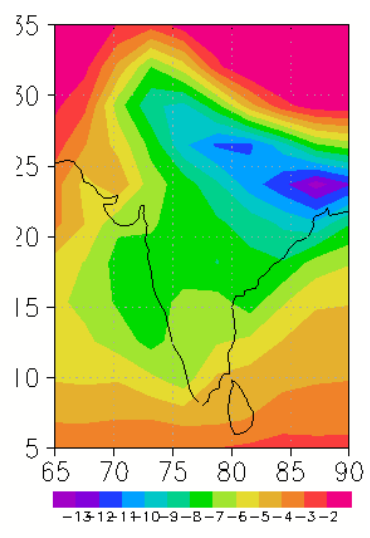

GiPOS: COLARIOES

Figure 5. Seven-year average anthropogenic radiative forcing (in $\mathrm{W} \mathrm{m}^{-2}$ ) in the area $65-90^{\circ} \mathrm{E}, 5-35^{\circ} \mathrm{N}$ in the MAIN simulation with GAINS emissions and without aerosol-cloud activation at the top of the atmosphere (left) and at the surface (right).

of the northwestern part at and beyond the national border in March-May. As expected, the mixed-layer ocean simulations show a stronger cooling over the ocean due to aerosols than fixed-SST experiments, and the cooling is relatively uniform, being about $0.5^{\circ} \mathrm{C}$ and varying with location and season. There is no particular north-south gradient to be seen in the temperature anomaly over the sea. Thus the gradient assumed for the SSTMODIF and SSTMODIF_ACT sensitivity calculations might not be realistic. However, as mentioned before, also the mixed-layer ocean simulation results should be interpreted cautiously. Prasad et al. (2009) report a positive temperature trend in the north in winter months with the MAIN simulation showing a similar anomaly, though with the MAIN_ACT and MAIN_MLO simulations rather showing cooling in winter.

\section{The model monsoon and aerosol effects on it}

ECHAM5 is a world-class model in simulating the monsoon according to Kripalani et al. (2007). The coupled model ECHAM5-MPI-OM simulates the monsoon seasonal cycle and spatial patterns qualitatively correctly (Rajeevan and Nanjundiah, 2009). The intraseasonal oscillation (ISO) was simulated reasonably well already by the previousgeneration model ECHAM4 (Kemball-Cook and Wang, 2001). However, ECHAM5 has like many other models a double-Intertropical Convergence Zone problem (Lin, 2007), which might have to do with problems simulating ISO propagations (Rajeev and Nanjundiah, 2007). Abhik et al. (2013) recognize a potential bias related to moist physics and convection. For additional evaluation in this article, based on the suggestion of Sud (2014), we compare the current ECHAM5-HAM results with ERA-Interim reanalysis fields for the high pressure ridge in northern India in March-May 

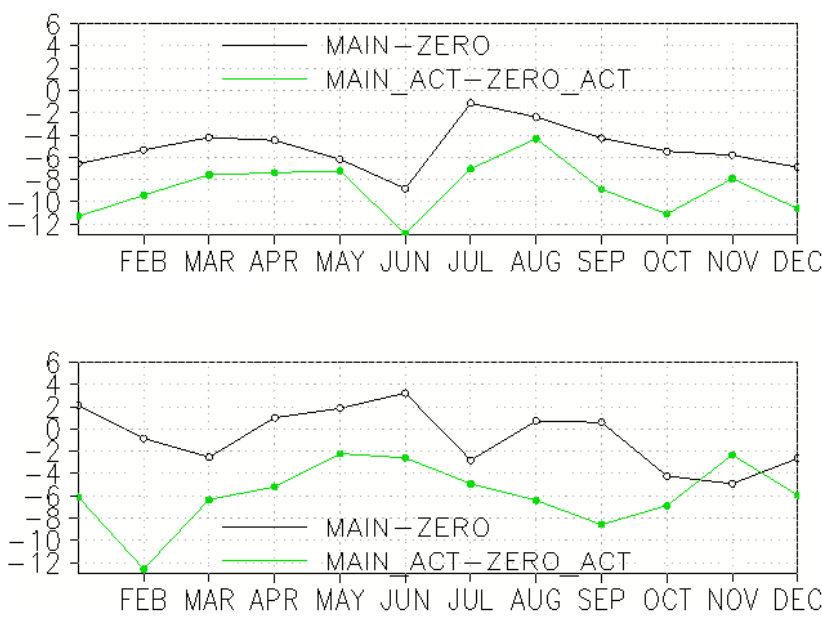

Figure 6. Seven-year monthly mean anthropogenic SW+LW radiation flux anomalies (in $\mathrm{W} \mathrm{m}^{-2}$ ) in the area $65-90^{\circ} \mathrm{E}, 5-35^{\circ} \mathrm{N}$ in the MAIN and MAIN_ACT simulations with GAINS emissions (a) at the surface and (b) at the TOA (black: without, green: with aerosol-cloud activation).
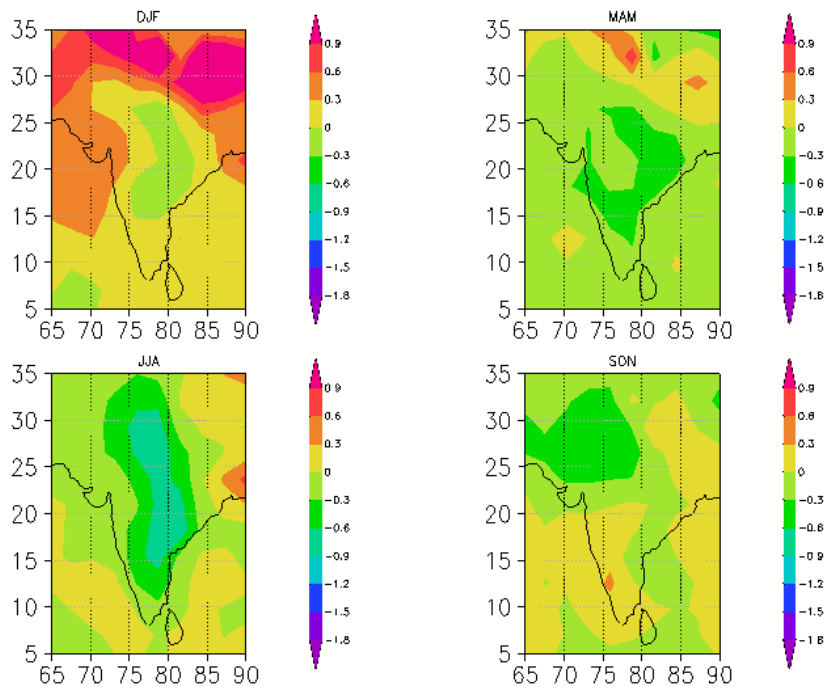

Figure 7. Seven-year seasonal $2 \mathrm{~m}$ temperature anomalies (in $\mathrm{K}$ ) in the MAIN simulation with GAINS emissions and without aerosol activation.

and the monsoon trough in June-August. The results in the form of the geopotential height at 500 mbar show qualitative correspondence in Supplement Fig. S2.

Knowing that the model performs well in simulating the Indian monsoon and the Indian aerosol distributions, with the possible exceptions of the Thar Desert and the Indo-Gangetic plains with high absorption (Henriksson et al., 2011), we proceed to investigate the effects of the aerosols on rainfall during different seasons. As is well known and seen in Supplement Fig. S5, cloud cover builds up in different parts of India during May-June and declines again around the end
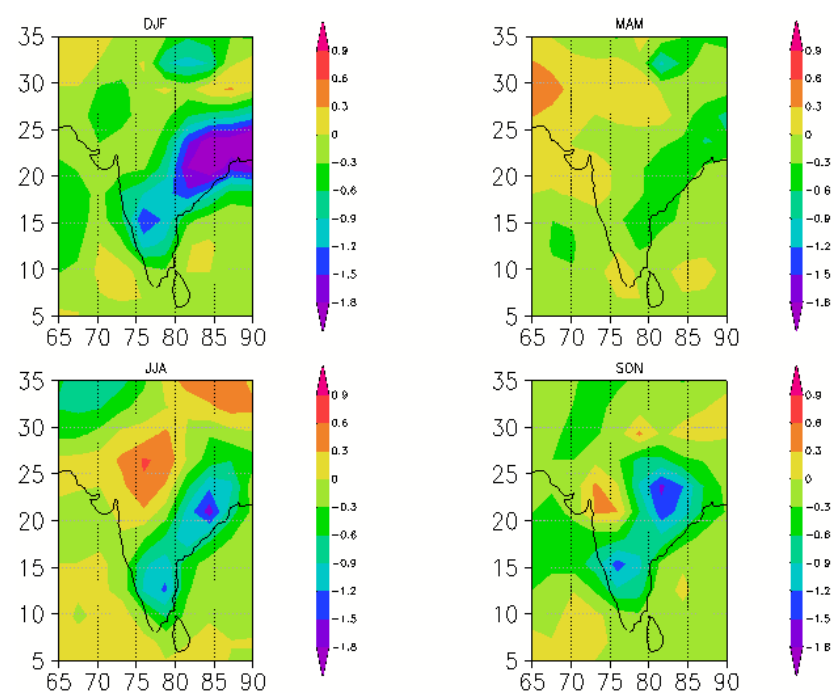

Figure 8. Seven-year seasonal $2 \mathrm{~m}$ temperature anomalies (in $\mathrm{K}$ ) in the MAIN_ACT simulation with GAINS emissions and aerosol activation.

of September. Thus, before the monsoon, the albedo of the ground and clouds combined will be relatively low while the wet removal is relatively weak and vice versa after the monsoon onset. This will have consequences for the aerosol effects on atmospheric temperatures at different levels during different seasons and, further, on cloud cover and rainfall. One implication is seen in the previous section: especially during the months of May and June with high cloud cover and low wet removal, absorbing aerosols manage to increase the number of high clouds enough to produce a positive net radiative anomaly.

Figure 10 shows the seasonal cycle of rainfall in the area $65-90^{\circ} \mathrm{E}, 20-35^{\circ} \mathrm{N}$ in the different simulations. It can be seen that the model simulates significantly more rainfall in northern India when aerosol-cloud activation or the mixedlayer ocean is included compared to the atmospheric model without cloud activation only. In all model setups, the effect of anthropogenic aerosols is to reduce rainfall in July and August. During some of the months of March-May, the MAIN and MAIN_MLO simulations conversely show an increase of precipitation due to anthropogenic aerosols. It has been suggested that increased rainfall in March-May could through soil moisture cause a delayed negative feedback as increased cloudiness would lead to surface cooling and reduced evaporation (Lau and Kim, 2006; Meehl et al., 2008). If assuming that the north-south SST gradient reduces by $0.5^{\circ} \mathrm{C}$ due to aerosols as in the SSTMODIF experiments, monsoon rainfall decreases a lot in northern India, as shown in Supplement Fig. S6. However, even though loosely deduced from observations as a historical change (Ramanathan et al., 2005), the gradient might not reflect the real effect of aerosols in the model as the mixed-layer ocean simulations show a more uniform cooling of the ocean (temperature 

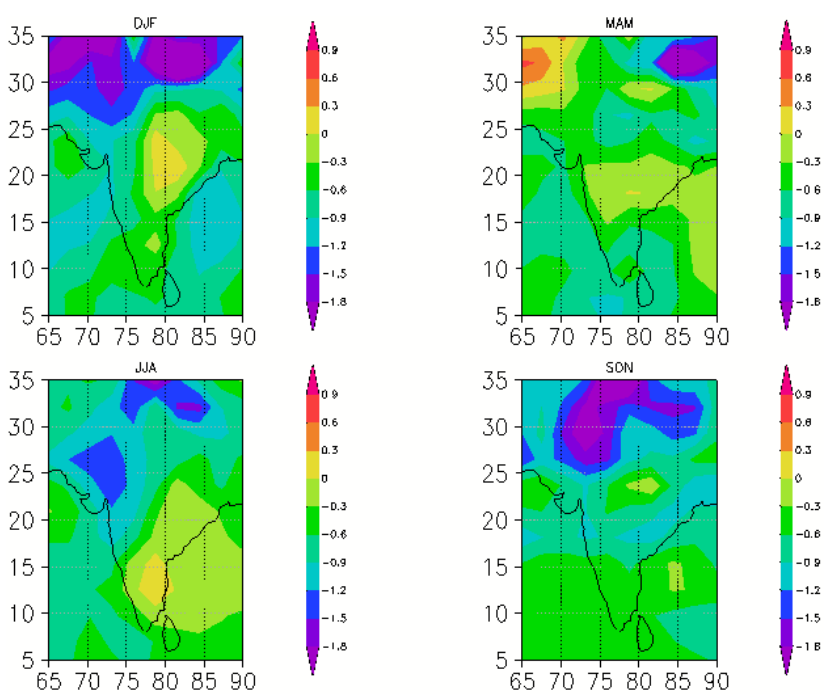

Figure 9. Ten-year seasonal $2 \mathrm{~m}$ temperature anomalies (in $\mathrm{K}$ ) in the MAIN_MLO simulation with GAINS emissions and without aerosol activation.

anomalies shown in the previous section and supported by radiative forcing data, which was not shown). The historical SST change is influenced besides aerosols by greenhouse gas warming, low-frequency internal climate variability and other factors.

Aerosol light absorption generally increases rainfall in the monsoon months June-August, with the slight exception of August when aerosol-cloud activation is included. In March-May, the effect of absorption seems to be neutral. As light absorption increases rainfall in northern India in the monsoon months and the aggregate effect of aerosols is to reduce it, we conclude that both the EHP and SDM mechanisms are active, with the SDM mechanisms being stronger and leading to a negative total precipitation anomaly in the ECHAM5-HAM model. However, it is good to keep in mind the anomalies of opposite sign during March-May. If this is a realistic result, it could partly explain controversial responses raised by the EHP hypothesis and resolve the controversy by the explanation of different responses in different times of the year. Nigam and Bollasina (2010) partly use aerosol-rainfall correlations in May in arguments against the EHP hypothesis, and Kuhlmann and Quaas (2010) rely on CALIPSO lidar satellite aerosol observations in March-May. Below in this section, we shall look more closely at related variables of atmospheric physics, and in Sect. 6 we study some correlations between AOD and rainfall in different seasons.

Supplement Fig. S7 shows spatial patterns of precipitation and evaporation anomalies in the different model setups. Especially in June-August, it is interesting that even strong precipitation anomalies are not accompanied by corresponding evaporation anomalies, but the water apparently stays in the soil. Figures 11 and 12 show time-pressure level plots for the aerosol effects on cloud cover and vertical ve-
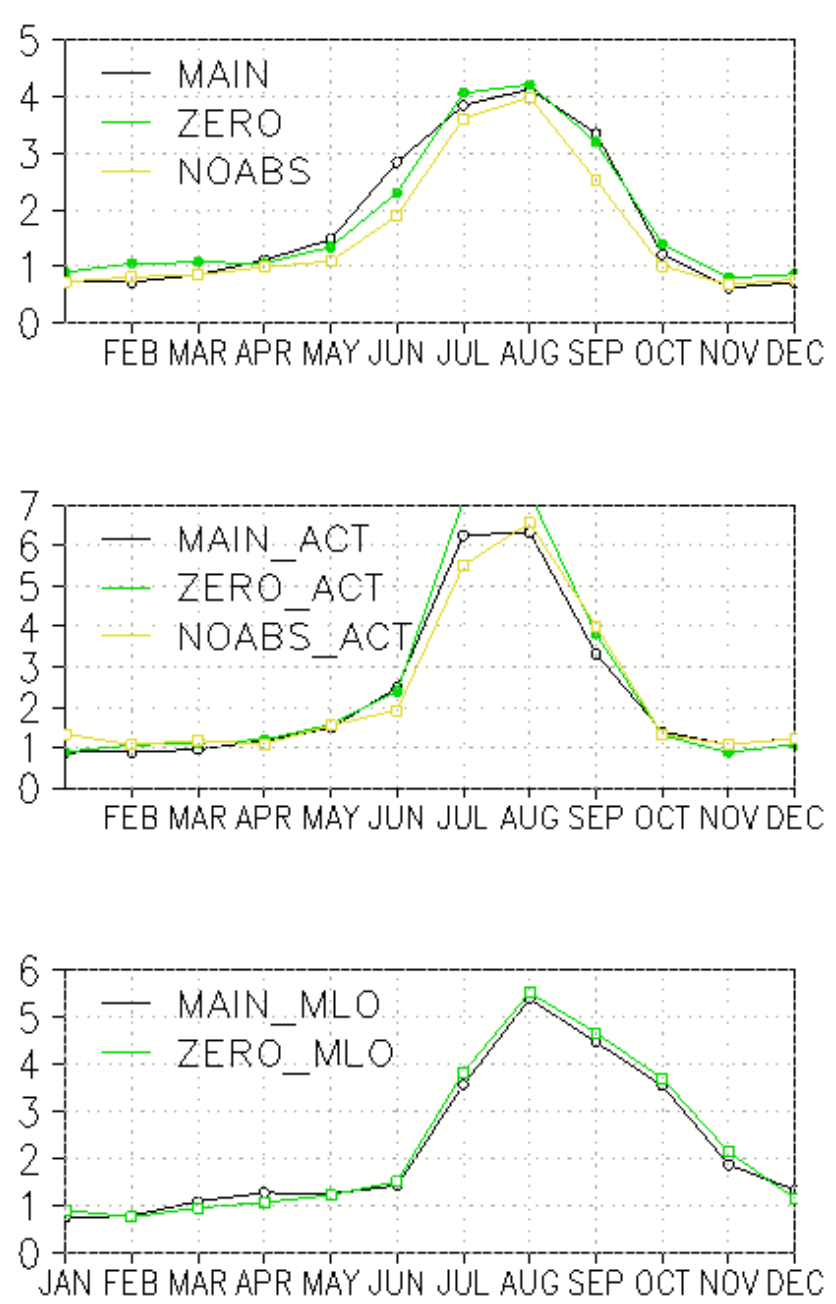

Figure 10. Seven-year monthly mean precipitation $\left(\mathrm{mm} \mathrm{d}^{-1}\right)$ in the longitude-latitude box $65-90^{\circ} \mathrm{E}, 20-35^{\circ} \mathrm{N}$ for simulations above without aerosol-cloud activation (black: MAIN, green: ZERO, yellow: NOABS) and below with aerosol-cloud activation (black: MAIN_ACT, green: ZERO_ACT, yellow: NOABS_ACT).

locity. The simulations with zero anthropogenic emissions and without absorption are taken as a reference (Supplement Fig. S5 shows the reference climatology). In general, the cloud cover and vertical velocity anomalies due to absorption (MAIN-NOABS and MAIN_ACT-NOABS_ACT) tend to be positive in June-August, supporting a strong EHP in the summer months. However, when taking the full aerosol atmospheric effects into account (MAIN-ZERO and MAIN_ACT-ZERO_ACT), the same effect is weaker and even turns around in July and August. When examining the rainfall reduction effect in the sensitivity calculations SSTMODIF and SSTMODIF_ACT, it is strongly negative. Increased atmospheric CDNC concentrations contribute to the solar dimming. A rough estimate for typical in-cloud CDNC concentrations in India in July is $250 \mathrm{~cm}^{-3}$ (based on inverting averages of available output). There is 
theoretical and observational support for rain invigoration in moist environments with increasing CDNC (Rosenfeld et al., 2008), but the complex aerosol microphysical effects on convective clouds were not parameterized in this study.

An important explaining factor behind the effect of light absorption in northern India is the climatological cloud cover (shown in Supplement Fig. S5): before the monsoon onset around mid-June there are few clouds, and after the monsoon onset there are many more clouds. Thus before the monsoon onset more light can pass through to the lightabsorbing material near the surface to increase the vertical velocity through increased buoyancy. To explain the negative monsoon rain anomalies, a proposed delayed negative cloud feedback could act alongside or even instead of the SDM in June-August after increased rainfall in spring due to aerosols and following increased evaporation and cloud formation (Lau and Kim, 2006; Meehl et al, 2008). However, the MAIN_ACT-ZERO_ACT rainfall anomaly is approximately zero in spring and still monsoon rainfall is reduced, which does not support a large importance of the cloud feedback. Instead, simply reduced solar radiation at the surface is likely more important, together with circulation changes and other mechanisms. Evaporation in Supplement Fig. S7 also does not show increased evaporation over the northern areas of the subcontinent in June-August due to aerosols when cloud activation is included. However, increased cloud cover visible in May could support a partial delayed cloud feedback effect. Based on the earlier reasoning related to Fig. 6 and Supplement Fig. S4, a combined EHP-SDM effect also seems possible: aerosol light absorption increases upward motion and high clouds increasing longwave trapping in the atmosphere but also incoming shortwave radiation to a smaller extent. It would be interesting to examine these effects in total rainfall in different circumstances when accounting for reduced solar radiation and thus evaporation and convection at the surface as well as the effects in the higher troposphere.

Further time-pressure level plots are shown in the Supplement, showing specific humidity, temperature and relative humidity (Supplement Figs. S8-10) and including the sensitivity calculations with modified fixed SSTs. Supplement Fig. S11 shows tropospheric temperature and surface wind anomalies. Summarizing the results, aerosols cause warming especially in February-March throughout the troposphere due to reduced cloud cover involving a semidirect effect. Gautam et al. (2009) and Lau and Kim (2010) point out that warmer tropospheric temperatures in the pre-monsoon season are consistent with the EHP hypothesis. Indeed, the effect of absorption alone seems to warm the troposphere more consistently during the pre-monsoon season, whereas April and May already show colder anomalies when all atmospheric aerosol effects are taken into account. In JuneAugust, the surface cools in all simulations except in the sensitivity calculations, where instead the higher troposphere cools. Specific humidity in the troposphere decreases in June-September in the MAIN_ACT and SSTMODIF_ACT
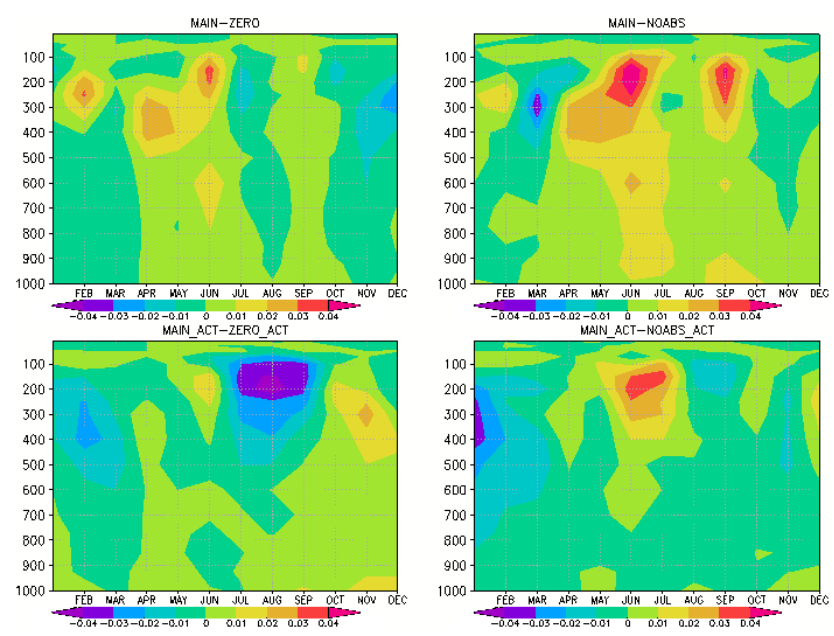

Figure 11. Cloud cover anomalies averaged over the longitudelatitude box $65-90^{\circ} \mathrm{E}, 5-35^{\circ} \mathrm{N}$ at different pressure levels in the different simulations, 7-year monthly means.
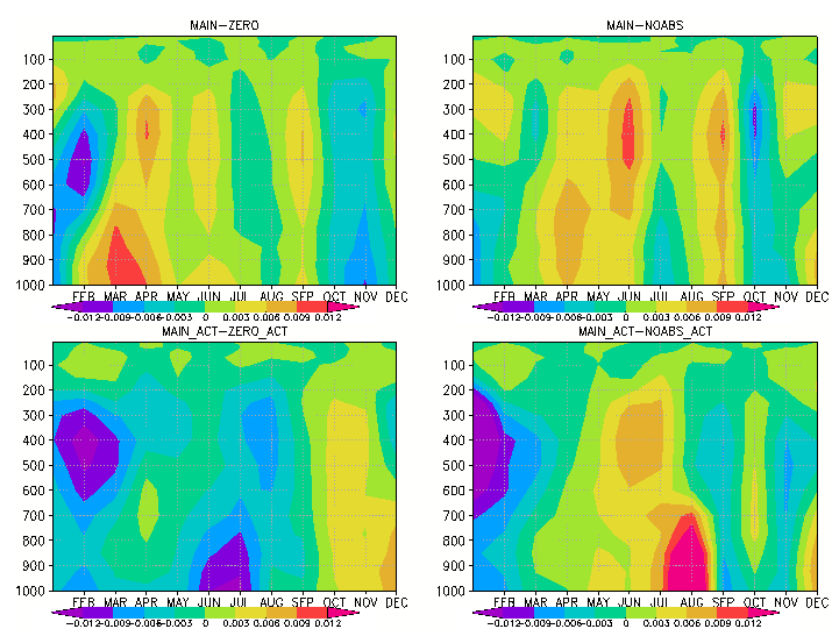

Figure 12. Vertical velocity anomalies averaged over the longitudelatitude box $65-90^{\circ} \mathrm{E}, 5-35^{\circ} \mathrm{N}\left(-\mathrm{Pa} \mathrm{s}^{-1}\right)$ at different pressure levels in the different simulations, 7-year monthly means.

simulations, probably largely due to reduced evaporation. Thus, with enough cooling included in the form of dimming or artificially reduced SST, reduced humidity due to decreased evaporation could also be an important part of the aerosol effect on rainfall. In the MAIN-ZERO case, the reduction in rainfall seems to require an increased tropospheric temperature and decreasing relative humidity despite growing specific humidity. Relative humidity anomalies follow the cloud cover anomalies quite strongly. Aerosol absorption seems to cause stronger tropospheric heating over northern India (Supplement Fig. S11), whereas the other model setups show no particular such monsoon-enhancing features and the artificially modified SST cases show a strong cooling over 

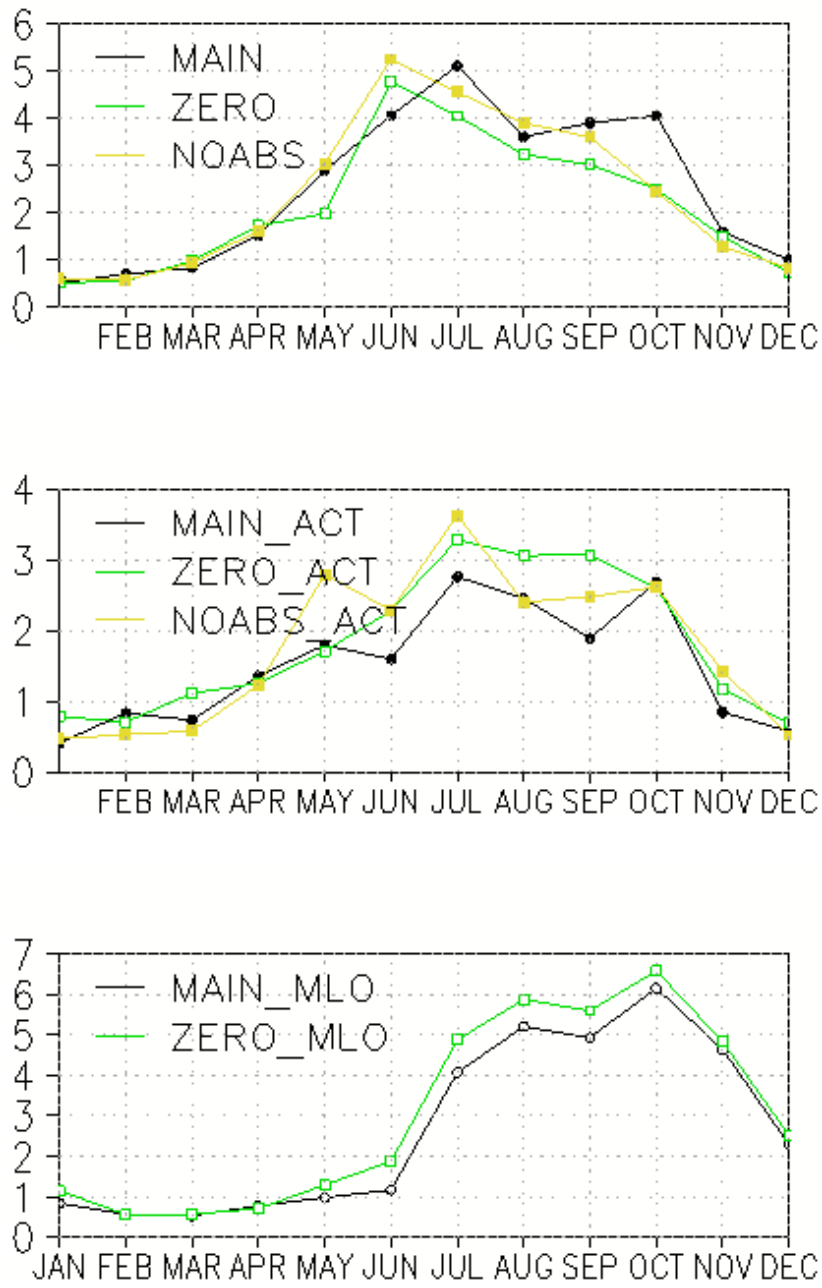

Figure 13. Rainfall in the area $75-80^{\circ} \mathrm{E}, 10-20^{\circ} \mathrm{N}$ in the simulations above) without aerosol-cloud activation (black: MAIN, green: ZERO, yellow: NOABS) and below with aerosol-cloud activation (black: MAIN_ACT, green: ZERO_ACT, yellow: NOABS_ACT), 7-year monthly means.

northern India, which apparently weakens the monsoon in the experiments SSTMODIF and SSTMODIF_ACT.

In June-August, the negative precipitation anomaly due to aerosols in the mixed-layer ocean setup is small despite strong atmospheric forcing (about $-2 \mathrm{~W} \mathrm{~m}^{-2}$ in July). The TOA forcing is close to zero ( $0.03 \mathrm{~W} \mathrm{~m}^{-2}$ in July), perhaps suggesting competing opposite effects. The effects do not necessarily add up linearly, however. A positive rainfallevaporation feedback combining solar dimming and light absorption has been suggested (Lee et al., 2013). Inherently nonlinear strong contributions from aerosols transported from far have also been suggested (Wang et al., 2009; Ganguly et al., 2012a).

Figure 13 shows rainfall in more southern parts of India: $10-20^{\circ} \mathrm{N}, 75-80^{\circ} \mathrm{E}$. In these parts, the rainfall is more evenly distributed over the year than in the northern parts

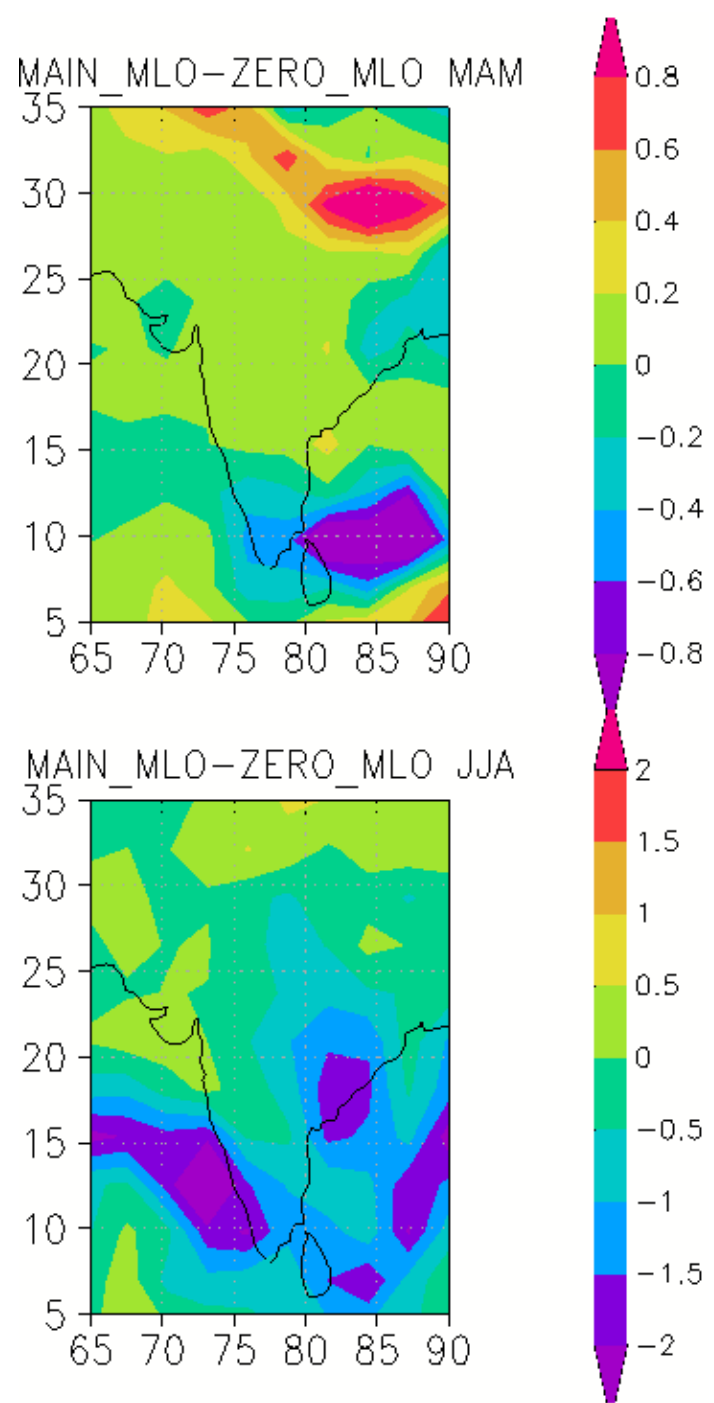

Figure 14. Spatial rainfall anomaly patterns in the mixed-layer ocean simulations for March-May (above) and June-August (below), 10-year monthly means.

where the monsoon months' rainfall dominates and, in contrast to northern India, more rainfall in the simulations without aerosol-cloud activation. Effects of aerosols are not the same as in northern India and are less robust over different model setups: anthropogenic aerosols decrease rainfall when cloud activation or the mixed-layer ocean is included, but increase rainfall in the MAIN-ZERO case. This part of India is influenced by larger water vapor transport from the seas on both sides than in the north, likely to make the aerosol effect more complex.

Finally, Fig. 14 shows the precipitation anomaly spatial patterns in the mixed-layer ocean simulations. The positive precipitation anomalies in March-May are particularly strong over the Himalayan slopes, while the negative precipitation anomalies in June-August are strongest in the more 
southern part of the subcontinent and over the seas. As seen by comparing with the distributions is Supplement Fig. S7, the anomalies are like the temperature anomalies different depending on whether the mixed-layer ocean is included or not. Consistent with the results of Ganguly et al. (2012b), the largest differences between model setups are shown at more southern latitudes, logically consistent with the fact that slow oceanic responses could be more important in the south, where the seas are closer to the average continental location. The rainfall anomaly for northern India is, however, consistently negative in all cases. Our results thus do not support a positive total precipitation response due to the nonlinear interplay between the EHP and SDM mechanisms as discussed by Lee et al. (2013).

\section{Interpreting AOD-rainfall correlations}

AOD-rainfall correlations and anticorrelations are tempting for making conclusions about aerosol effects on rainfall, and they have been both used and disputed as partial arguments for or against certain mechanisms in the literature (Nigam and Bollasina, 2010, 2011; Lau and Kim, 2011). With model simulation data available, we can in the following present a few points regarding correlation interpretations that to our knowledge have not been presented in the literature before that might help to increase the understanding of how correlations and anticorrelations may arise.

As within each simulation, the anthropogenic emissions are the same during all the simulated years, the aerosol concentration and precipitation interannual variability is caused by internal variability (and the aerosol feedback on it), mainly by the different sea surface temperatures in different years. This is particularly the case in the nine simulations without interactive mixed-layer ocean. Thus a correlation or anticorrelation between aerosols and rainfall will mainly be determined by the different SST fields acting as different atmospheric boundary conditions during the different years.

In the area $20-35^{\circ} \mathrm{N}, 65-90^{\circ} \mathrm{E}$ in some years, winds in April are more westerly, bringing more dust and - at the same time - drier air, implying a higher AOD but a lower precipitation, indicating a negative correlation between AOD and precipitation (shown in Fig. 15a). At the same time, the correlation is strongly positive in July (shown in Fig. 15b), explained by aerosol hygroscopic growth during years with more precipitation accompanied by a high relative humidity in general and a resulting increased AOD. This is illustrated further in Supplement Fig. S12, showing that the interannual variability in AOD is indeed mostly explained by mineral dust AOD in April and by aerosol water in July. The same figure shows that AOD correlates positively with $10 \mathrm{~m} u$-wind anomaly both in April and July. In July, however, the wind is more southwesterly, explaining why similar positive (westerly) $u$-wind anomalies on average bring more dry, dusty air to the area of interest in April and more moist air, imply- ing more hygroscopic growth of aerosols and precipitation in July. Aerosol scavenging would cause negative correlation between aerosol concentrations and precipitation were it the sole effect, and it has contributed for example to the negative correlation seen in Fig. 15a. A delayed correlation circumvents this effect, and June AOD vs. July precipitation tells a similar story (not shown). Based on the analyses done above, we make the interpretation that similar interannual large-scale wind variability is largely behind the observed interannual anticorrelation.

In conclusion of this section, aerosol-rainfall correlations should be used very cautiously when deducing causality.

\section{Conclusions}

The Indian climate was simulated in a series of eleven simulations applying the aerosol-climate model ECHAM5-HAM and the GAINS emission inventory. The goal was to investigate aerosol radiative forcing with temperature and precipitation response in the model. The model was evaluated against observed aerosol optical properties and surface concentration measurements in an earlier article. Here, additional comparisons for BC concentrations in Mukteshwar and for features of the monsoon circulation were made. The model performs well both in simulating the Indian monsoon and aerosol distributions over India, though with certain known biases and potential problems. In addition to the challenges brought by the general complexity of the problem, aerosol distributions over the Thar Desert and the Indo-Gangetic plains and physical processes related to convection and Himalayan orography were identified as possible error sources. Still, considering the model's good performance and keeping the limitations in mind, the model can well be used for estimating the aerosol effects on the climate.

Simulations were performed with and without aerosolcloud activation separately, with and without absorption of shortwave radiation, with and without artificially cooled sea surface temperatures in the northern Indian Ocean as sensitivity analyses, and one simulation was nudged by ERAInterim reanalysis weather fields. Additionally, simulations with a mixed-layer ocean model were done for an estimate of the ocean response and its effects on temperature and rainfall over the Indian subcontinent.

Total negative aerosol forcing at the TOA was strongest in the summer, and anthropogenic forcing, including that of light-absorbing $\mathrm{BC}$, was strongest in the winter. While the Indian average forcing was found negative in all months and all model setups, in the simulation with GAINS emissions and no aerosol-cloud activation there were locations with positive mean forcing. In the summer months, the Indian average radiation anomalies at the TOA were positive due to the semidirect aerosol cloud effect and other effects turning the small negative forcing into a positive anomaly in the radiative balance. Seasonal temperature anomalies were mainly 

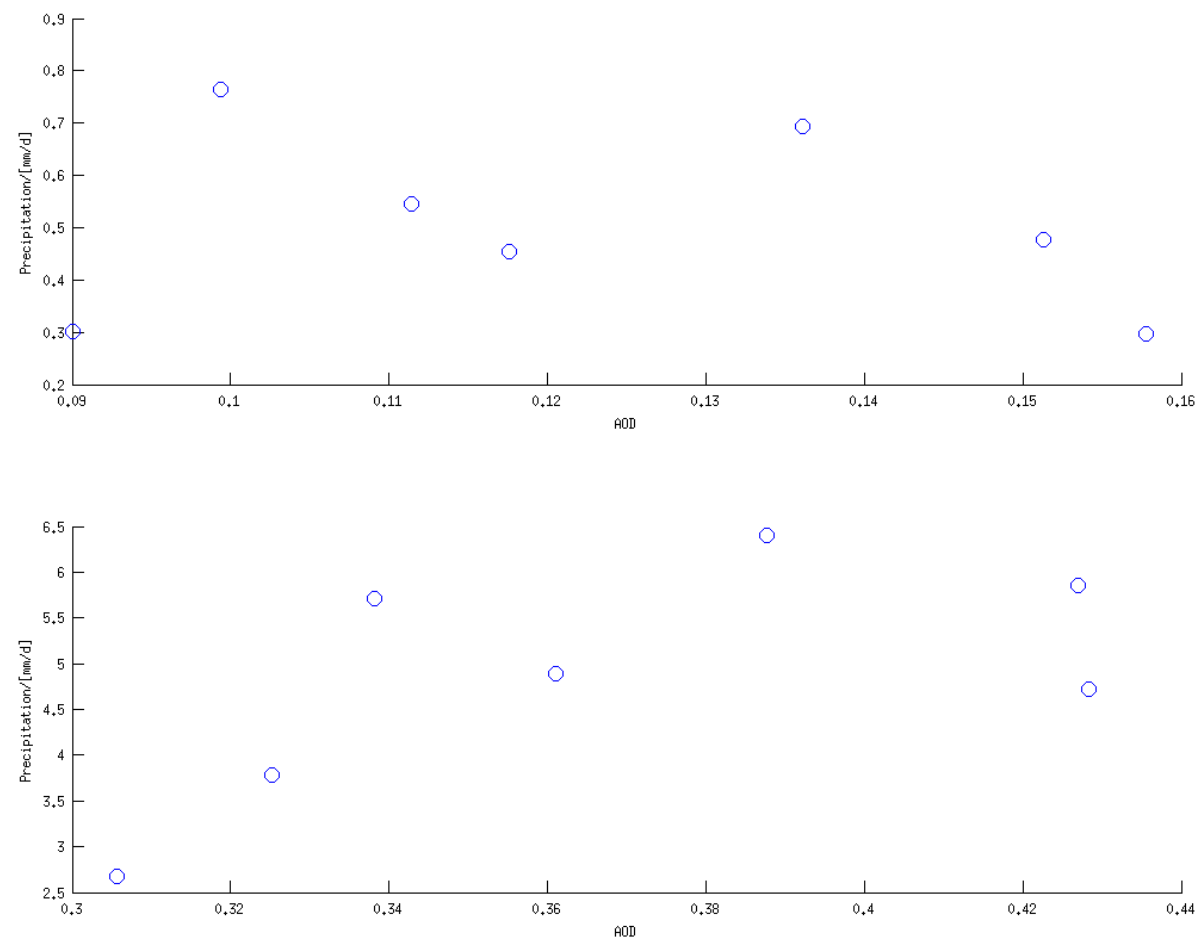

Figure 15. Values of mean AOD and mean precipitation for separate years in the area $65-90^{\circ} \mathrm{E}, 20-35^{\circ} \mathrm{N}$ in April (above) and July (below), MAIN_ACT simulation.

negative and locally on the order of up to $2^{\circ} \mathrm{C}$, but especially in the pre-monsoon months of March-May there were local positive anomalies north of $25^{\circ} \mathrm{N}$ both with and without aerosol-cloud activation. Spatial distributions were somewhat different when the mixed-layer ocean was included.

As for rainfall, the model serves as a tool for separately studying different, opposing effects and for studying separate mechanisms with, of course, scope for model development and evaluation remaining. Our results provide support for the elevated heat pump (EHP) mechanism, which increases vertical velocity and monsoon rainfall in northern India. However, reduced solar radiation at the surface, circulation changes as well as reduced surface evaporation caused by the aerosols seem to nearly or more than cancel out these effects. Before the monsoon onset with smaller cloud cover more light absorption may happen, whereafter solar dimming generally seems to become relatively stronger, especially if considering aerosol-cloud activation. Therefore the total effect of aerosols on rainfall in the monsoon months of June-August seems to be negative. A possibly newly identified mechanism could be a combined EHP-SDM, whereby aerosol light absorption causes tropospheric warming, increases average vertical velocity and consequently high cloudiness. Interestingly, this may cause a positive net TOA radiation anomaly despite negative radiative forcing due to more trapped longwave radiation while incoming solar radiation is reduced. It would be interesting to study further what the total effect on rainfall is in different circumstances. A small increase or decrease in precipitation in March-May was observed due to absorption, depending on the model setup, connected with decreased cloudiness due to semidirect aerosol effects during these months. This could help resolve apparent contradictions between different earlier results in the literature as arguments against the EHP have often focused on the months of March to May (Kuhlmann and Quaas, 2010; Nigam and Bollasina, 2010), when we also find a negative correlation between AOD and rainfall in northern India in the example presented in Sect. 6. The correlation changes to positive in July. The correlation and anticorrelation are rather caused by internal variability of the ocean and atmosphere than by aerosols affecting precipitation as the emissions are the same in each simulated year. Such correlations should therefore be used very cautiously when investigating causality.

We hope to have contributed to the ongoing discussion about aerosol-climate interactions in India and especially the EHP and SDM mechanisms by making simulations with setups allowing the separate study of the effects of aerosol light absorption, total atmospheric effects of anthropogenic aerosols as well as possible effects of oceanic responses through mixed-layer ocean simulations and sensitivity analyses with modified fixed SSTs. The results are completely dependent on how realistic the model is and should be interpreted cautiously. Nevertheless, combined with physical reasoning, observations and other results, they may be useful 
in forming hypotheses about the real physical monsoon and in interpreting observations. This important topic certainly merits further research and discussion.

\section{The Supplement related to this article is available online at doi:10.5194/acp-14-10177-2014-supplement.}

Acknowledgements. Financial support by the Ministry for Foreign Affairs of Finland, the Academy of Finland (project numbers 127210, 129355 and 140748 and the project number 118615 of the National Centre of Excellence in Research Programme), EU LIFE+ LIFE09 (ENV/FI/000572 MACEB) as well as the strategic funding of the University of Eastern Finland is gratefully acknowledged. Gridding of the emission data by C. Heyes is gratefully acknowledged.

Edited by: X. Liu

\section{References}

Abhik, S., Mukhopadhyay, P., Goswami, B. N.: Evaluation of mean and intraseasonal variability of Indian summer monsoon simulation in ECHAM5: identification of possible source of bias, Clim. Dynam., 33, 1-18, doi:10.1007/s00382-013-1824-7, 2013.

Amann, M., Bertok, I., Borken-Kleefeld, J., Cofala, J., Heyes, C., Hoeglund-Isaksson, L., Klimont, Z., Nguyen, B., Posch, M., Rafaj, P., Sandler, R., Schoepp, W., Wagner, F., and Winiwarter, W.: Cost-effective control of air quality and greenhouse gases in Europe: Modeling and policy applications, Environ. Modell. Soft., 26, 1489-1501, 2011.

Andres, R. J. and Kasgnoc, A. D.: A time-averaged inventory of subaerial volcanic sulfur emissions, J. Geophys. Res., 103, 25251-25261, 1998.

Anonymous Referee \#2: Interactive Comment on "Climatic effects of 1950-2050 changes in US anthropogenic aerosols - Part 2: Climate response" by E. M. Leibensperger et al., Atmos. Chem. Phys. Discuss., 11, C10881-C10883, 2011.

Anonymous Referee \#3: Interactive Comment on "Climatic effects of 1950-2050 changes in US anthropogenic aerosols - Part 2: Climate response" by E. M. Leibensperger et al., Atmos. Chem. Phys. Discuss., 11, C10798-C10800, 2011.

Bollasina, M., Nigam, S., and Lau, K. M.: Absorbing aerosols and summer monsoon evolution over South Asia: An observational portrayal, J. Climate, 21, 3221-3239, 2008.

Bollasina, M. and Nigam, S.: Absorbing aerosols and presummer monsoon hydroclimate variability over the Indian subcontinent: The challenge in investigating links, Atmos. Res., 94, 338-344, 2009.

Brohan, P., Kennedy, J. J., Harris, I., Tett, S. F. B., and Jones, P. D.: Uncertainty estimates in regional and global observed temperature changes: A new data set from 1850, J. Geophys. Res., 111, 12106, doi:10.1029/2005JD006548, 2006.

Chung, C. E. and Ramanathan, V.: Weakening of Northern Indian SST gradients and the monsoon rainfall in India and the Sahel, J. Climate, 19, 2036-2045, 2006.
Corbett, J. J., Lack, D. A., Winebrake, J. J., Harder, S., Silberman, J. A., and Gold, M.: Arctic shipping emissions inventories and future scenarios, Atmos. Chem. Phys., 10, 9689-9704, doi:10.5194/acp-10-9689-2010, 2010.

de Laat, A. T. J., Stein Zweers, D. C., Boers, R., and Tuinder, O. N. E.: A solar escalator: Observational evidence of the self-lifting of smoke and aerosols by absorption of solar radiation in the February 2009 Australian Black Saturday plume, J. Geophys. Res., 117, D04204, doi:10.1029/2011JD017016, 2012.

Eyring, V., Isaksen, I. S. A., Berntsen, T., Collins, W. J., Corbett, J. J., Endresen, O., Grainger, R. G., Moldanova, J., Schlager, H., and Stevenson, D. S.:Transport impacts on atmosphere and climate: Shipping, Atmos. Environ., 44, 4735-4771, 2010.

Ganguly, D., Rasch, P. J., Wang, H., and Yoon, J.-H.: Climate response of the South Asian monsoon system to anthropogenic aerosols, J. Geophys. Res., 117, D13209, doi:10.1029/2012JD017508, 2012a.

Ganguly, D., Rasch, P. J., Wang, H., and Yoon, J.-H.: Fast and slow responses of the South Asian monsoon system to anthropogenic aerosols, Geophys. Res. Lett., 39, L18804, doi:10.1029/2012GL053043, 2012b.

Gautam, R., Hsu, N. C., Lau, K. M., Tsay, S. C., and Kafatos, M.: Enhanced pre-monsoon warming over the Himalayan-Gangetic region from 1979 to 2007, Geophys. Res. Lett., 36, L07704, doi:10.1029/2009GL037641, 2009.

GEA, Global Energy Assessment - Toward a Sustainable Future, Cambridge University Press, Cambridge UK and New York, NY, USA and the International Institute for Applied Systems Analysis, Laxenburg, Austria, 2012.

Giglio, L., Randerson, J. T., van der Werf, G. R., Kasibhatla, P. S., Collatz, G. J., Morton, D. C., and DeFries, R. S.: Assessing variability and long-term trends in burned area by merging multiple satellite fire products, Biogeosciences, 7, 1171-1186, doi:10.5194/bg-7-1171-2010, 2010.

Guenther, A., Hewitt, C. N., Erickson, D., Fall, R., Geron, C., Graedel, T., Harley, P., Klinger, L., Lerdau, M., McKay, W. A., Pierce, T., Scholes, B., Steinbrecher, R., Tallamraju, R., Taylor, J., and Zimmerman, P.: A global model of natural volatile organic compound emissions, J. Geophys. Res., 100, 8873-8892, 1995.

Halmer, M. M., Schmincke, H.-U., and Graf, H.-F.: The annual volcanic gas input into the atmosphere, in particular into the stratosphere: a global data set for the past 100 years, J. Volcanol. Geoth. Res., 115, 511-528, 2002.

Henriksson, S. V., Laaksonen, A., Kerminen, V.-M., Räisänen, P., Järvinen, H., Sundström, A.-M., and de Leeuw, G.: Spatial distributions and seasonal cycles of aerosols in India and China seen in global climate-aerosol model, Atmos. Chem. Phys., 11, 79757990, doi:10.5194/acp-11-7975-2011, 2011.

Hyvärinen, A.-P., Lihavainen, H., Komppula, M., Sharma V. P., Kerminen V.-M., Panwar, T. S., and Viisanen Y.: Continuous measurements of optical properties of atmospheric aerosols in Mukteshvar, Northern India, J. Geophys. Res., 114, D08207, doi:10.1029/2008JD011489, 2009.

Hyvärinen, A.-P., Raatikainen, T., Brus, D., Komppula, M., Panwar, T. S., Hooda, R. K., Sharma, V. P., and Lihavainen, H.: Effect of the summer monsoon on aerosols at two measurement stations in Northern India - Part 1: PM and BC concentrations, Atmos. Chem. Phys., 11, 8271-8282, doi:10.5194/acp-11-82712011, 2011a. 
Hyvärinen, A.-P., Raatikainen, T., Komppula, M., Mielonen, T., Sundström, A.-M., Brus, D., Panwar, T. S., Hooda, R. K., Sharma, V. P., de Leeuw, G., and Lihavainen, H.: Effect of the summer monsoon on aerosols at two measurement stations in Northern India - Part 2: Physical and optical properties, Atmos. Chem. Phys., 11, 8283-8294, doi:10.5194/acp-11-82832011, $2011 b$.

Kemball-Cook, S. and Wang, B.: Equatorial waves and air-sea interaction in the boreal summer intraseasonal oscillation, J. Climate, 14, 2923-2942, 2001.

Klimont, Z., Cofala, J., Xing, J., Wei, W., Zhang, C., Wang, S., Kejun, J., Bhandari, P., Mathur, R., Purohit, P., Rafaj, P., Chambers, A., Amann, M., and Hao, J.: Projections of $\mathrm{SO}_{2}, \mathrm{NO}_{\mathrm{x}}$ and carbonaceous aerosols emissions in Asia, Tellus, 61, 602-617, 2009.

Komppula, M., Lihavainen, H., Hyvärinen, A.-P., Kerminen, V.-M., Panwar, T. S., Sharma, V. P., and Viisanen, Y.: Physical properties of aerosol particles at a Himalayan background site in India, J. Geophys. Res., 114, D12202, doi:10.1029/2008JD011007, 2009.

Kripalani, R. H., Oh, J. H., Kulkarni, A., Sabade, S. S., and Chaudhari, H. S.: South Asian summer monsoon precipitation variability: Coupled climate model simulations and projections under IPCC AR4, Theor. Appl. Climatol., 90, 133-159, 2007.

Kuhlmann, J. and Quaas, J.: How can aerosols affect the Asian summer monsoon? Assessment during three consecutive premonsoon seasons from CALIPSO satellite data, Atmos. Chem. Phys., 10, 4673-4688, doi:10.5194/acp-10-4673-2010, 2010.

Lamarque, J.-F., Bond, T. C., Eyring, V., Granier, C., Heil, A., Klimont, Z., Lee, D., Liousse, C., Mieville, A., Owen, B., Schultz, M. G., Shindell, D., Smith, S. J., Stehfest, E., Van Aardenne, J., Cooper, O. R., Kainuma, M., Mahowald, N., McConnell, J. R., Naik, V., Riahi, K., and van Vuuren, D. P.: Historical (1850-2000) gridded anthropogenic and biomass burning emissions of reactive gases and aerosols: methodology and application, Atmos. Chem. Phys., 10, 7017-7039, doi:10.5194/acp10-7017-2010, 2010.

Lau, K.-M. and Kim, K.-M.: Observational relationships between aerosol and Asian monsoon rainfall, and circulation, Geophys. Res. Lett., 33, L21810, doi:10.1029/2006GL027546, 2006.

Lau, K. M. and Kim, K. M.: Comment on Elevated heat pump hypothesis for the aerosol-monsoon hydroclimate link: Grounded in observations by S. Nigam and M. Bollasina, J. Geophys. Res., 116, D07203, doi:10.1029/2010JD014800, 2011.

Lau, W. K. M. and Kim, K.-M.: Fingerprinting the impacts of aerosols on longterm trends of the Indian summer monsoon regional rainfall, Geophys. Res. Lett., 37, L16705, doi:10.1029/2010GL043255, 2010.

Lau, K.-M., Kim, M. K., and Kim, K.-M.: Aerosol induced anomalies in the Asian summer monsoon: The role of the Tibetan Plateau, Clim. Dynam., 26, 855-864, doi:10.1007/s00382-0060114-z, 2006.

Lau, K., Ramanathan, V., Wu, G., Li, Z., Tsay, S., Hsu, C., Sikka, R., Holben, B., Lu, D., Tartari, G., Chin, M., Koudelova, R., Chen, H., Ma, Y., Huang, J., Taniguchi, K., and Zhang, R: The Joint Aerosol-Monsoon Experiment (JAMEX): A new challenge to monsoon climate research, B. Am. Meteorol. Soc., 89, 369383, doi:10.1175/BAMS-89-3-369, 2008.

Lee, S.-J., Shin, H.-J., and Wang, C.: Nonlinear Effects of Coexisting Surface and Atmospheric Forcing of Anthropogenic Ab- sorbing Aerosols: Impact on the South Asian Monsoon Onset, J. Climate, 26, 5594-5607, doi:10.1175/JCLI-D-12-00741.1, 2013.

Levermann, A., Schewe, J., Petoukhov, V., and Held, H.: Basic mechanism for abrupt monsoon transitions, P. Natl. Acad. Sci. USA, 106, 20572-20577, doi:10.1073/pnas.0901414106, 2009.

Lin, H. and Leaitch, W. R.: Development of an in-cloud aerosol activation parameterization for climate modelling. Proceedings of the WMO Workshop on Measurement of Cloud Properties for Forecasts of Weather, Air Quality and Climate, Mexico City, June, 328-335, 1997.

Lin, J.-L.: The Double-ITCZ Problem in IPCC AR4 Coupled GCMs: Ocean-Atmosphere Feedback Analysis, J. Climate, 20, 4497-4525, doi:10.1175/JCLI4272.1, 2007.

Marcq, S., Laj, P., Roger, J. C., Villani, P., Sellegri, K., Bonasoni, P., Marinoni, A., Cristofanelli, P., Verza, G. P., and Bergin, M.: Aerosol optical properties and radiative forcing in the high Himalaya based on measurements at the Nepal Climate Observatory-Pyramid site (5079 m a.s.1.), Atmos. Chem. Phys., 10, 5859-5872, doi:10.5194/acp-10-5859-2010, 2010.

Marsland, S. J., Haak, H., Jungclaus, J. H., Latif, M., and Roske F.: The Max-Planck-Institute global ocean/sea ice model with orthogonal curvilinear coordinates, Ocean. Model., 5, 91-127, 2003.

Meehl, G. A., Arblaster, J. M., and Collins, W. D.: Effects of black carbon aerosols on the Indian monsoon, J. Climate, 21, 28692882, 2008.

Medina, S., Houze, R. A., Kumar, A., and Niyogi, D.: Summer monsoon convection in the Himalayan region: Terrain and land cover effects, Q. J. R. Meteorol. Soc., 136, 593-616, doi:10.1002/qj.601, 2010.

Menon, A., Levermann, A., Schewe, J., Lehmann, J., and Frieler, K.: Consistent increase in Indian monsoon rainfall and its variability across CMIP-5 models, Earth Syst. Dynam., 4, 287-300, doi:10.5194/esd-4-287-2013, 2013.

Miyamoto, Y., Kajikawa, Y., Yoshida, R., Yamaura, T., Yashiro, H., and Tomita, H.: Deep moist atmospheric convection in a subkilometer global simulation, Geophys. Res. Lett., 40, 4922-4926, doi:10.1002/grl.50944, 2013.

Moorthy, K. K., Babu, S. S., and Satheesh, S. K.: Aerosol characteristics and radiative impacts over the Arabian Sea during the intermonsoon season: Results from ARMEX field campaign, J. Atmos. Sci., 62, 192-206, 2004.

Nakicenovic, N., Alcamo, J., Davis, G., de Vries, B., Fenhann, J., Gaffin, S., Gregory, K., Grübler, A., Jung, T. Y., Kram, T., Lebre La Rovere, E., Michaelis, L., Mori, S., Morita, T., Pepper, W., Pitcher, H., Price, L., Riahi, K., Roehrl, A., Rogner, H.-H., Sankovski, A., Schlesinger, M., Shukla, P., Smith, S., Swart, R., van Rooijen, S., Victor, N., and Dadi, Z.: IPCC special report on emission scenarios. Cambridge University Press, Cambridge, 599 pp., 2000.

Neitola, K., Asmi, E., Komppula, M., Hyvärinen, A.-P., Raatikainen, T., Panwar, T. S., Sharma, V. P., and Lihavainen, H.: New particle formation infrequently observed in Himalayan foothills - why?, Atmos. Chem. Phys., 11, 8447-8458, doi:10.5194/acp-11-8447-2011, 2011.

Nigam, S. and Bollasina, M.: Elevated heat pump hypothesis for the aerosol-monsoon hydroclimate link: Grounded in observations?, J. Geophys. Res., 115, D16201, doi:10.1029/2009JD013800, 2010. 
Nigam, S. and Bollasina, M.: Reply to comment by K. M. Lau and K. M. Kim on Elevated heat pump hypothesis for the aerosolmonsoon hydroclimate link: Grounded in observations, J. Geophys. Res., 116, D07204, doi:10.1029/2010JD015246, 2011.

Niranjan, K., Sreekanth, V., Madhavan, B. L., and Krishna Moorthy, K.: Aerosol physical properties and Radiative forcing at the outflow region from the Indo-Gangetic plains during typical clear and hazy periods of wintertime, Geophys. Res. Lett., 34, L19805, doi:10.1029/2007GL031224, 2007.

Ohara, T., Akimoto, H., Kurokawa, J., Horii, N., Yamaji, K., Yan, X., and Hayasaka, T.: An Asian emission inventory of anthropogenic emission sources for the period 1980-2020, Atmos. Chem. Phys., 7, 4419-4444, doi:10.5194/acp-7-4419-2007, 2007.

Padma Kumari, B., Londhe, A. L., Daniel, S., and Jadhav, D. B.: Observational evidence of solar dimming: Offsetting surface warming over India, Geophys. Res. Lett., 34, L21810, doi:10.1029/2007GL031133, 2007.

Pathak, B., Kalita, G., Bhuyan, K., Bhuyan, P. K., and Moorthy, K. K.: Aerosol temporal characteristics and its impact on shortwave radiative forcing at a location in the northeast of India, J. Geophys. Res., 115, D19204, doi:10.1029/2009JD013462, 2010.

Pham, M., Muller, J. F., Brasseur, G., Granier, C., and Megie, G.: A three-dimensional study of the tropospheric sulfur cycle, J. Geophys. Res. 100, 26061-26092, 1995.

Prasad, A. K., Yang, K.-H. S., El-Askary, H. M., and Kafatos, M.: Melting of major Glaciers in the western Himalayas: evidence of climatic changes from long term MSU derived tropospheric temperature trend (1979-2008), Ann. Geophys., 27, 4505-4519, doi:10.5194/angeo-27-4505-2009, 2009.

Purohit, P., Amann, M., Mathur, R., Gupta, I., Marwah, S., Verma, V., Bertok, I., Borken, J., Chambers, A., Cofala, C., Heyes, C., Hoglund, L., Klimont, K., Rafaj, P., Sandler, R., Schöpp, W., Toth, G., Wagner, F., and Winiwarter, W.: Scenarios for costeffective control of air pollution and greenhouse gases in India, GAINS report, available at: http://www.iiasa.ac.at/publication/ more_XO-10-061.php (last access: 18 September 2014), 2010.

Ramanathan, V. and Carmichael, G.: Global and regional climate changes due to black carbon, Nat. Geosci., 1, 221-227, 2008.

Ramanathan, V. and Feng, Y: Air pollution, greenhouse gases and climate change: Global and regional perspectives, Atmos. Environ., 43, 37-50, 2009.

Ramanathan, V., Crutzen, P. J., Lelieveld, J., Mitra, A. P., Althausen, D., Anderson, J., Andreae, M. O., Cantrell, W., Cass, G. R., Chung, C. E., Clarke, A. D., Coakley, J. A., Collins, W. D., Conant, W. C., Dulac, F., Heintzenberg, J., Heymsfield, A. J., Holben, B., Howell, S., Hudson, J., Jayaraman, A., Kiehl, J. T., Krishnamurti, T. N., Lubin, D., McFarquhar, G., Novakov, T., Ogren, J. A., Podgorny, I. A., Prather, K., Priestley, K., Prospero, J. M., Quinn, P. K., Rajeev, K., Rasch, P., Rupert, S., Sadourny, R., Satheesh, S. K., Shaw, G. E., Sheridan, P., and Valero, F. P. J.: Indian Ocean Experiment: An integrated analysis of the climate forcing and effects of the great Indo-Asian haze, J. Geophys. Res., 106, 28371-28398, 2001.

Ramanathan, V., Chung, C., Kim, D., Bettge, T., Buja, L., Kiehl, J. T., Washington, W. M., Fu, Q., Sikka, D. R., and Wild, M.: Atmospheric brown clouds: Impact on South Asian climate and hydrologic cycle, P. Natl. Acad. Sci. USA, 102, 5326-5333, doi:10.1073/pnas.0500656102, 2005.
Ramanathan, V., Li, F., Ramana, M. V., Praveen, P. S., Kim, D., Corrigan, C. E., Nguyen, H., Stone, E. A., Schauer, J. J., Carmichael, G. R., Adhikary B., and Yoon, S. C.: Atmospheric brown clouds: Hemispherical and regional variations in long-range transport, absorption and radiative forcing, J. Geophys. Res., 112, D22S2, doi:10.1029/2006JD008124, 2007

Roeckner, E., Bäuml, G., Bonaventura, L., Brokopf, R., Esch, M., Giorgetta, M., Hagemann, S., Kirchner, I., Kornblueh, L., Manzini, E., Rhodin, A., Schlese, U., Schulzweida, U., and Tompkins,A.: The atmospheric general circulation model ECHAM5. Part I: Model description, Report 349, Max Planck Institute for Meteorology, Hamburg, Germany, available at: http://www.mpimet.mpg.de/fileadmin/publikationen/Reports/ max_scirep_349.pdf (last access: 18 September 2014), 2003.

Roeckner, E., Brokopf, R., Esch, M., Giorgetta, M., Hagemann, S., Kornblueh, L., Manzini, E., Schlese, U., and Schulzweida, U.: Sensitivity of Simulated Climate to Horizontal and Vertical Resolution in the ECHAM5 Atmosphere Model, J. Climate, 19, 3771-3791, 2006a.

Roeckner, E., Stier, P., Feichter, J., Kloster, S., Esch, M., and Fischer-Bruns, I.: Impact of carbonaceous aerosol emissions on regional climate change, Clim. Dynam., 27, 553-571, 2006b.

Rosenfeld, D., Lohmann, U., Raga, G. B., O’Dowd, C. D., Kulmala, M., Fuzzi, S., Reissell, A., and Andreae, M. O.: Flood or Drought: How Do Aerosols Affect Precipitation?, Science, 321, 1309-1313, 2008.

Stier, P., Feichter, J., Kinne, S., Kloster, S., Vignati, E., Wilson, J., Ganzeveld, L., Tegen, I., Werner, M., Balkanski, Y., Schulz, M., Boucher, O., Minikin, A., and Petzold, A.: The aerosol-climate model ECHAM5-HAM, Atmos. Chem. Phys., 5, 1125-1156, doi:10.5194/acp-5-1125-2005, 2005.

Stier, P., Seinfeld, J. H., Kinne, S., and Boucher, O.: Aerosol absorption and radiative forcing, Atmos. Chem. Phys., 7, 5237-5261, doi:10.5194/acp-7-5237-2007, 2007.

Streets, D. G., Bond, T. C., Carmichael, G. R., Fernandes, S. D., Fu, Q., He, D., Klimont, Z., Nelson, S. M., Tsai, N. Y., Wang, M. Q., Woo, J.-H., and Yarber, K. F.: An inventory of gaseous and primary aerosol emissions in Asia in the year 2000, J. Geophys. Res., 108, 8809, doi:10.1029/2002JD003093, 2003.

Sud, Y. C.: Interactive comment on "Spatial distributions and seasonal cycles of aerosol climate effects in India seen in global climate-aerosol model" by S. V. Henriksson et al., Atmos. Chem. Phys. Discuss., 13, C5985-C5991, 2013

Tuinstra, W.: Preparing for the European Thematic Strategy on air pollution: at the interface between science and policy, Environ. Sci. Pollut., 10, 434-444, 2007.

Uppala, S. M., Kallberg, P. W., Simmons, A. J., Andrae, U., Bechtold, V. D. C., Fiorino, M., Gibson, J. K., Haseler, J., Hernandez, A., Kelly, G. A., Li, X., Onogi, K., Saarinen, S., Sokka, N., Allan, R. P., Andersson, E., Arpe, K., Balmaseda, M. A., Beljaars, A. C. M., Berg, L. V. D., Bidlot, J., Bormann, N., Caires, S., Chevallier, F., Dethof, A., Dragosavac, M., Fisher, M., Fuentes, M., Hagemann, S., Holm, E., Hoskins, B. J., Isaksen, L., Janssen, P. A. E. M., Jenne, R., Mcnally, A. P., Mahfouf, J.-F., Morcrette, J.-J., Rayner, N. A., Saunders, R. W., Simon, P., Sterl, A., Trenberth, K. E., Untch, A., Vasiljevic, D., Viterbo, P., and Woollen, J.: The ERA-40 re-analysis, Q. J. Roy. Meteor. Soc., 131, 29613012, doi:10.1256/qj.04.176, 2005. 
van der Werf, G. R., Randerson, J. T., Giglio, L., Collatz, G. J., Mu, M., Kasibhatla, P. S., Morton, D. C., DeFries, R. S., Jin, Y., and van Leeuwen, T. T.: Global fire emissions and the contribution of deforestation, savanna, forest, agricultural, and peat fires (19972009), Atmos. Chem. Phys., 10, 11707-11735, doi:10.5194/acp10-11707-2010, 2010.

Verma, S., Venkataram, C., and Boucher, O.: Attribution of aerosol radiative forcing over India during the winter monsoon to emissions from source categories and geographical regions, Atmos. Environ., 45, 4398-4407, 2011.
Wang, C., Kim, D., Ekman, A. M. L., Barth, M. C., and Rasch, P. J.: Impact of anthropogenic aerosols on Indian summer monsoon, Geophys. Res. Lett., 36, L21704, doi:10.1029/2009GL040114, 2009.

$\mathrm{Xu}, \mathrm{Q}$.: Abrupt change of the mid-summer climate in central East China by the influence of atmospheric pollution, Atmos. Environ., 35, 5029-5040, 2001. 